\title{
Financial Constraint, Property Right and Cost of Capital
}

\author{
Zhijie Wan \\ School of Management, Jinan University, Guangzhou, China \\ Email: wanzhijie2@163.com
}

How to cite this paper: Wan, Z. J. (2020). Financial Constraint, Property Right and Cost of Capital. Modern Economy, 11, 443-452.

https://doi.org/10.4236/me.2020.112033

Received: January 16, 2020

Accepted: February 18, 2020

Published: February 21, 2020

Copyright $\odot 2020$ by author(s) and Scientific Research Publishing Inc. This work is licensed under the Creative Commons Attribution International License (CC BY 4.0).

http://creativecommons.org/licenses/by/4.0/

\begin{abstract}
This paper examines the impact of financing constraint risk on the cost of equity capital, and finds that there is a significant positive correlation between the financing constraint risk and the cost of equity capital. The greater the financing constraint risk is, the greater the cost of equity capital is, and state-owned enterprises can mitigate the impact of financing constraint on the cost of equity capital. For companies that do not disclose the protection of shareholders' equity in the annual report, their financing constraint risk has an impact on the cost of equity capital. The influence of cost is more significant.
\end{abstract}

\section{Keywords}

Financial Constraint, Cost of Equity Capital, Property Right

\section{Introduction}

For China's economic development, financing constraints have become one of the important bottlenecks restricting economic transformation and upgrading. The report of the World Bank shows that some non-financial listed enterprises in China choose to list financing constraints as the main obstacle to the development of enterprises, with the highest proportion in 80 surveyed countries. Chinese enterprises generally believe that financing constraints are the main constraint to their development. At present, the existing research mainly focuses on how the financing constraints affect the operation of Chinese enterprises and how to get rid of the financing constraints.

Financing constraint refers to the relative investment opportunities of enterprises and the difficulty of obtaining funds. Financing constraint will inevitably increase the operational risk of enterprises, which is also called financing con- 
straint risk. White \& $\mathrm{Wu}$ (2006) verified that the risk of financing constraints can increase the expected return of stocks by constructing a three-factor model of financing constraints group's portfolio and code. The measurement of the cost of equity capital includes the measurement of the cost of equity capital in advance (ICC) and the cost of equity capital after the event. In the estimation of ICC, the measurement of the cost of equity capital gets rid of the dependence on the fluctuation of stock price and the data of stock returns realized in the past, and has stronger explanatory power on the future returns. Therefore, it can measure the financing constraint risk and capital formation more accurately than previous studies. Through financing constraints, including equity financing constraints and debt financing constraints, this paper tests that voluntary disclosure of shareholders' rights and interests protection can alleviate financing constraints, finds that this disclosure can eliminate information asymmetry between the market and enterprises, and discloses that enterprises with shareholders' rights and interests protection can get the trust of external investors, so that the impact of financing constraints on the cost of equity capital is not significant. Obviously, the financing constraint risk of undisclosed enterprises still significantly affects the cost of equity capital.

\section{Theoretical Analysis and Research Hypothesis}

MM theory holds that, in a perfect capital market, the value of an enterprise mainly depends on the investment behavior of the enterprise and has nothing to do with the financing behavior of the enterprise, but the real market is not perfect. When an enterprise chooses financing methods, it must consider the differences between the costs of different methods, which will change with the changes of the financing behavior of the enterprise. When an enterprise is faced with a financing contract. The research of Fazzari and Athey (1987) shows that the market imperfection caused by the information asymmetry will make the enterprises face the problem of financing constraints, that is, the investment opportunities of enterprises cannot get sufficient financial support. Because the formation of financing constraints is closely related to market imperfection, it is difficult to disperse its risks. Some researchers clearly point out that the financing constraint is that in the case of imperfect capital market, there will be differences between internal and external financing, so the problem of financing constraint must be considered. When enterprises have financing constraints, they are bound to be limited when they choose financing methods, and then affect the necessary rate of return of external investors, that is, the cost of enterprise capital. From the micro point of view, the reason why enterprises have financing constraints is mainly based on information asymmetry and principal-agent problems. The degree of financing constraint reflects the degree of credit asymmetry between managers and external investors and the severity of agency contradiction between managers and owners. With the gradual increase of information asymmetry, the information cost and agency cost of principal-agent will in- 
crease, and the expected return rate of shareholders will increase in the future. Based on the above analysis, the first assumption of this paper is proposed:

$\mathrm{H} 1$ : The higher the degree of financing constraints enterprises face, the higher the cost of equity capital.

In China, the government and state-owned enterprises play a leading role in the national economy. Many studies have shown that the social responsibility behavior of Chinese enterprises is driven by the government's power. Enterprises reach a kind of resource exchange with the government by fulfilling their social responsibility, so as to obtain the government's help in debt financing. Therefore, the disclosure of social responsibility information may help enterprises obtain the support of the government and banks, so as to ease the financing constraints. Considering China's specific national conditions, compared with private enterprises, state-owned enterprises have obvious advantages in property rights protection, government enterprise relations, financing treatment and other aspects. Therefore, from the perspective of property heterogeneity, the impact mechanism of financing constraints and equity capital cost of state-owned enterprises may be different from that of private enterprises. Based on the above analysis, the second hypothesis is proposed:

$\mathrm{H} 2$ : When facing financing constraints, the cost of equity capital of state-owned enterprises is lower than that of private enterprises.

According to the MM theory of neoclassical economics, in the perfect market, all kinds of financing methods of enterprises can be completely replaced without financing constraints. However, in reality, the market is not perfect. The existence of information asymmetry and transaction cost makes the cost of different financing methods of enterprises different. The cost of external financing is higher than the cost of internal financing. Some enterprises may be difficult to finance from the outside or the cost of external financing is too high, resulting in financing constraints. Although the disclosure of corporate social responsibility information is not the same as the actual social responsibility, in the real situation, because of the information asymmetry, outsiders can only distinguish enterprises by the significant signal of whether to disclose the social responsibility information. The social responsibility information disclosed by enterprises has become one of the important references for the external evaluation of their actual performance. Information disclosure reduces the information asymmetry between the information owners and investors inside the enterprise, reduces the risk assessment of the expected return of the enterprise by the investors, thus reducing the required minimum return on investment; on the other hand, the information level obtained by different investors tends to be consistent, reduces the information asymmetry between different investors, and increases the liquidity of the stock, increase the demand for securities, so as to reduce the cost of equity capital. In conclusion, information disclosure can ease the financing constraints and reduce the cost of equity capital. When the specific information disclosed is the equity protection information directly related to financing con- 
straints and the creditor protection information, the information asymmetry between enterprises and investors can be relieved. The shadow price of equity financing, that is to say, increase the income of one unit of equity financing to perfect capital. The shadow price of this market is close, so the pricing function of financing constraints is weakened, and the mechanism of financing constraints on equity capital may be different.

Based on the above analysis, the third hypothesis is proposed:

H3: The impact of financing constraints on the cost of equity capital is not obvious.

\section{Data and Research Design}

\subsection{Sample}

In this paper, all listed companies in Shanghai and Shenzhen A-share market from 2007 to 2016 are used as the original samples, and the financial data are all from CSMAR database. CSMAR database is a large-scale, accurate and comprehensive economic and financial research database in China. According to the following rules, the samples are screened: 1) the listed companies in the financial industry are excluded; 2) the sample observations of St, ${ }^{*} \mathrm{ST}$ and delisting are excluded; 3) the companies listed for less than one year are excluded; 4) according to the requirements of PEG model, the samples with eps2-eps $1<0$ are excluded; 5) some companies with incomplete index data are excluded. After the above screening, 8102 observations are finally obtained. In order to eliminate the influence of extreme value, Winsorised processing is used for the main continuous variables in this paper, and stata11.0 statistical software is used for data processing and analysis.

\subsection{Data}

1) Financing constraints

There are three main methods to measure financing constraints. One is the sensitivity index of investment cash flow proposed by Almeida et al. (2010): the stronger the financing constraint, the higher the sensitivity of investment cash flow. Second, Kaplan \& Zingales (1997) designed KZ index based on the comprehensive weighting of a series of financial indicators. The third is the $\mathrm{WW}$ index of financing constraints based on the dynamic structure estimation method of White \& Wu (2006).

In theory, the degree of financing constraint can be indirectly reflected by many key financial indicators. Kaplan and Zingales (1997) for the first time take five factors as the proxy variables of financing constraints, such as net operating cash flow, cash holdings, cash payout level, debt level and growth, and then construct a comprehensive index ( $\mathrm{KZ}$ index) to measure the degree of financing constraints by regression analysis. Since then, this approach has been widely used in the research field of financing constraints. In this paper, the KZ index designed by Kaplan \& Zingales (1997) and the SA index proposed by Hadlock 
and Pierce (2010) are used.

2) Cost of equity capital

In view of the inaccuracy of the cost of equity capital after the event, in recent years scholars have turned their attention to the measurement of the cost of equity capital before the event. Gebhardt, Lee and Swaminathan (2001) proposed the concept of implied cost of capital. ICC is to make the present value of future cash flow equal to the internal rate of return of current stock price. In the estimation of ICC, the measurement of cost of equity capital gets rid of the dependence on the fluctuation of stock price and the data of stock income realized in the past. This method of estimating cost of equity capital by using the data of stock price, short-term and long-term profit prediction provides another way for the measurement of cost of equity capital. At the same time, the research of information disclosure and performance evaluation related to cost of equity capital can also be pushed forward A big step forward.

The measurement of cost of equity capital in advance can be roughly divided into three categories: Gordon growth model, residual income model and abnormal earnings growth model (Hou, Dijk, \& Zhang, 2012). In this paper, PEG model is selected to measure the cost of equity capital of an enterprise, and it has been pointed out that PEG model is the most efficient to estimate the cost of equity capital, which can properly capture the impact of various risk factors, and has the advantages of simplicity and less restrictions.

$$
c O C=\sqrt{\left(e p s_{t+2}+e p s_{t+1}\right) / P_{t}}
$$

Among them, $P_{t}$ is the closing price of $T$ period of the stock, eps ${ }_{t+1}$ is the average value of each analyst's forecast value of earnings per share of $T+1$ period of the company, and $e^{2 p s_{t+2}}$ the average value of each analyst's forecast value of earnings per share of $T+2$ period of the company.

3) Control variable

Referring to the existing research on financing constraints and cost of equity capital, this paper selects the following indicators as control variables: Beta coefficient, total number of shares annual turnover rate (turnover), book to market ratio (BM), company size, financial leverage coefficient (Lev), return on total assets (ROA), return on net assets (ROE), annual virtual variables and industry viral variables. In group regression, this paper discusses the nature of ultimate control (state) and whether to disclose the protection of equity interests (edummy).

\subsection{Equations}

For hypothesis 1, we construct the following theoretical model:

$$
\begin{aligned}
\mathrm{COC}= & \beta_{1} \mathrm{FC}+\beta_{2} \text { Beta }+\beta_{3} \text { Turnover }+\beta_{4} \mathrm{BM}+\beta_{5} \text { Size } \\
& +\beta_{6} \mathrm{Lev}+\beta_{7} \mathrm{ROA}+\beta_{8} \mathrm{ROE}+\Sigma \text { industry }+\Sigma \text { year }
\end{aligned}
$$

Among them, FC is the main test variable, whose coefficient $\beta_{1}$ represents the impact of financial constraint on the cost of equity capital is predicted based on the above analysis. The result is positive. 
For hypothesis 2, we construct the following theoretical model:

$$
\begin{aligned}
\mathrm{COC}= & \beta_{1} \mathrm{FC}+\beta_{2} \text { State }+\beta_{3} \mathrm{FC} \times \text { State }+\beta_{4} \text { Beta }+\beta_{5} \text { Turnover }+\beta_{6} \mathrm{BM} \\
& +\beta_{7} \text { Size }+\beta_{8} \text { Lev }+\beta_{9} \mathrm{ROA}+\beta_{10} \mathrm{ROE}+\Sigma \text { industry }+\Sigma \text { year }
\end{aligned}
$$

Among them, the coefficient of the Intersection item represents the impact of nature of property right on the relation between FC and ICC. The result is negtive.

\section{Data and Methodology}

\subsection{Descriptive Statistics}

Table 1 shows, Kaplan and Zingales (1997) used KZ index to measure financial constraint (KZ), Hadlock and Pierce (2010) used SA index to measure financial constraint (SA) Implied cost of capital (COC), total number of shares annual turnover rate (turnover), book to market ratio (BM), company size, financial leverage coefficient (Lev), return on total assets (ROA), return on net assets (ROE), annual virtual variables and industry viral variables. In group regression, this paper discusses the nature of ultimate control (state) and whether to disclose the protection of equity interests (edummy).

\subsection{Empirical Test Results}

Table 2 shows, the regression results of columns 1 and 2 show that after controlling the industry and the year, when using $\mathrm{KZ}$ to measure financing constraints, the risk of facing 1 unit of financing constraints will increase the cost of capital by 0.0016 . Measuring financing constraints with SA, the risk of one unit of financing constraints increases the cost of capital by 0.0103 . Whether SA index or $\mathrm{KZ}$ index is used as financing constraint, the impact of financing constraint on the cost of equity capital is positive and very significant, indicating that the

Table 1. Descriptive statistics.

\begin{tabular}{cccccc}
\hline & Obersvation & Mean & Std. Dev. & Min. & Max \\
\hline COC & 8102 & 0.092 & 0.048 & 0.012 & 0.268 \\
KZ & 8102 & 1.216 & 1.102 & -2.510 & 3.534 \\
SA & 8102 & 4.225 & 1.454 & 1.687 & 9.531 \\
Beta & 8102 & 1.105 & 0.226 & 0.502 & 1.632 \\
Turnover & 8102 & 5.813 & 0.707 & 3.807 & 7.188 \\
BM & 8102 & 0.873 & 0.844 & 0.098 & 4.803 \\
Size & 8102 & 22.144 & 1.270 & 19.810 & 26.244 \\
Lev & 8102 & 1.460 & 1.093 & 0.671 & 8.300 \\
ROA & 8102 & 0.058 & 0.047 & 0.002 & 0.233 \\
ROE & 8102 & 0.110 & 0.081 & 0.003 & 0.417 \\
State & 8102 & 0.520 & 0.500 & 0 & 1 \\
EDummy & 8102 & 0.205 & 0.404 & 0 & 1 \\
\hline
\end{tabular}


Table 2. The relation between FC-ICC.

\begin{tabular}{|c|c|c|c|c|}
\hline & (1) & (2) & (3) & (4) \\
\hline \multirow[t]{2}{*}{$\mathrm{KZ}$} & $0.0016^{\star * *}$ & & $0.0025^{* * *}$ & \\
\hline & $(0.0091)$ & & $(0.0003)$ & \\
\hline \multirow[t]{2}{*}{ SA } & & $-0.0103^{* * *}$ & & $-0.0150^{\star * *}$ \\
\hline & & $(0.0000)$ & & $(0.0000)$ \\
\hline \multirow[t]{2}{*}{$\mathrm{KZ}^{\star}$ State } & & & $-0.0025^{\star * *}$ & \\
\hline & & & $(0.0078)$ & \\
\hline \multirow[t]{2}{*}{ SA*State } & & & & $0.0017^{\star *}$ \\
\hline & & & & $(0.0316)$ \\
\hline \multirow[t]{2}{*}{ State } & & & 0.0001 & $-0.0121^{\star * *}$ \\
\hline & & & $(0.9757)$ & $(0.0005)$ \\
\hline \multirow[t]{2}{*}{ Beta } & $-0.0094^{* * *}$ & $-0.0094^{* * *}$ & $-0.0092^{* * *}$ & $-0.0089^{* * *}$ \\
\hline & $(0.0006)$ & $(0.0006)$ & $(0.0008)$ & $(0.0011)$ \\
\hline \multirow[t]{2}{*}{ Turnover } & $0.0022^{\star *}$ & 0.0013 & $0.0024^{\star *}$ & 0.0014 \\
\hline & $(0.0373)$ & $(0.2061)$ & $(0.0231)$ & $(0.1809)$ \\
\hline \multirow[t]{2}{*}{$\mathrm{BM}$} & $0.0133^{\star * *}$ & $0.0141^{\star * *}$ & $0.0138^{\star * *}$ & $0.0141^{\star * *}$ \\
\hline & $(0.0000)$ & $(0.0000)$ & $(0.0000)$ & $(0.0000)$ \\
\hline \multirow[t]{2}{*}{ Size } & $-0.0029^{* * *}$ & $0.0086^{* * *}$ & $-0.0027^{* * *}$ & $0.0132^{* * *}$ \\
\hline & $(0.0000)$ & $(0.0003)$ & $(0.0000)$ & $(0.0000)$ \\
\hline \multirow[t]{2}{*}{ Lev } & $0.0036^{* * *}$ & $0.0038^{\star * *}$ & $0.0037^{\star * *}$ & $0.0037^{* * *}$ \\
\hline & $(0.0000)$ & $(0.0000)$ & $(0.0000)$ & $(0.0000)$ \\
\hline \multirow[t]{2}{*}{ ROA } & $-0.0623^{\star * *}$ & $-0.0803^{* * *}$ & $-0.0666^{* * *}$ & $-0.0845^{\star * *}$ \\
\hline & $(0.0086)$ & $(0.0001)$ & $(0.0050)$ & $(0.0001)$ \\
\hline \multirow[t]{2}{*}{ ROE } & $0.0356^{\star * *}$ & $0.0429^{* * *}$ & $0.0361^{\star * *}$ & $0.0427^{\star * *}$ \\
\hline & $(0.0032)$ & $(0.0001)$ & $(0.0028)$ & $(0.0001)$ \\
\hline \multirow[t]{2}{*}{ _cons } & $0.1136^{\star * *}$ & $-0.0855^{\star}$ & $0.1088^{* * *}$ & $-0.1654^{\star \star *}$ \\
\hline & $(0.0000)$ & $(0.0505)$ & $(0.0000)$ & $(0.0004)$ \\
\hline Industry & Y & Y & Y & Y \\
\hline Year & Y & Y & Y & Y \\
\hline Obs & 8102 & 8102 & 8102 & 8102 \\
\hline Adj-R & 0.174 & 0.176 & 0.176 & 0.178 \\
\hline
\end{tabular}

higher the financing constraint enterprises face, the higher the cost of equity capital, which is consistent with our expectation. The result shows that when the enterprise has the financing constraint, the enterprise must be limited in choosing the financing method, and then affect the necessary rate of return of the external investor, that is, the cost of the enterprise's capital. From the microcosmic point of view, the reason why enterprises have financing constraints is mainly based on information asymmetry and principal-agent problems. The degree of financing constraint reflects the degree of information asymmetry between business operators and outside investors and the severity of agency contradiction 
between business operators and owners. As the degree of information asymmetry of enterprises increases gradually, the information cost and agency cost of principal-agent will increase, and the rate of return expected by shareholders will rise in the future.

The regression results of columns 3 and 4 show that financing constraints and property rights are very significant, the coefficients of cross multiplication terms are -0.0025 and 0.0017 , respectively, which are opposite to the symbols of independent variables, which shows that state-owned enterprises can influence the cost of equity capital by financing constraints. The result shows that state-owned enterprises have obvious advantages in property rights protection, government-enterprise relations, financing treatment and so on. Corporate disclosure of social responsibility information may help them secure government and bank support, thereby easing financing constraints.

Table 3 shows, from the regression of the protection of the rights and interests of the disclosing shareholders in the first and second columns and the

Table 3. The relation between FC-ICC in different samples.

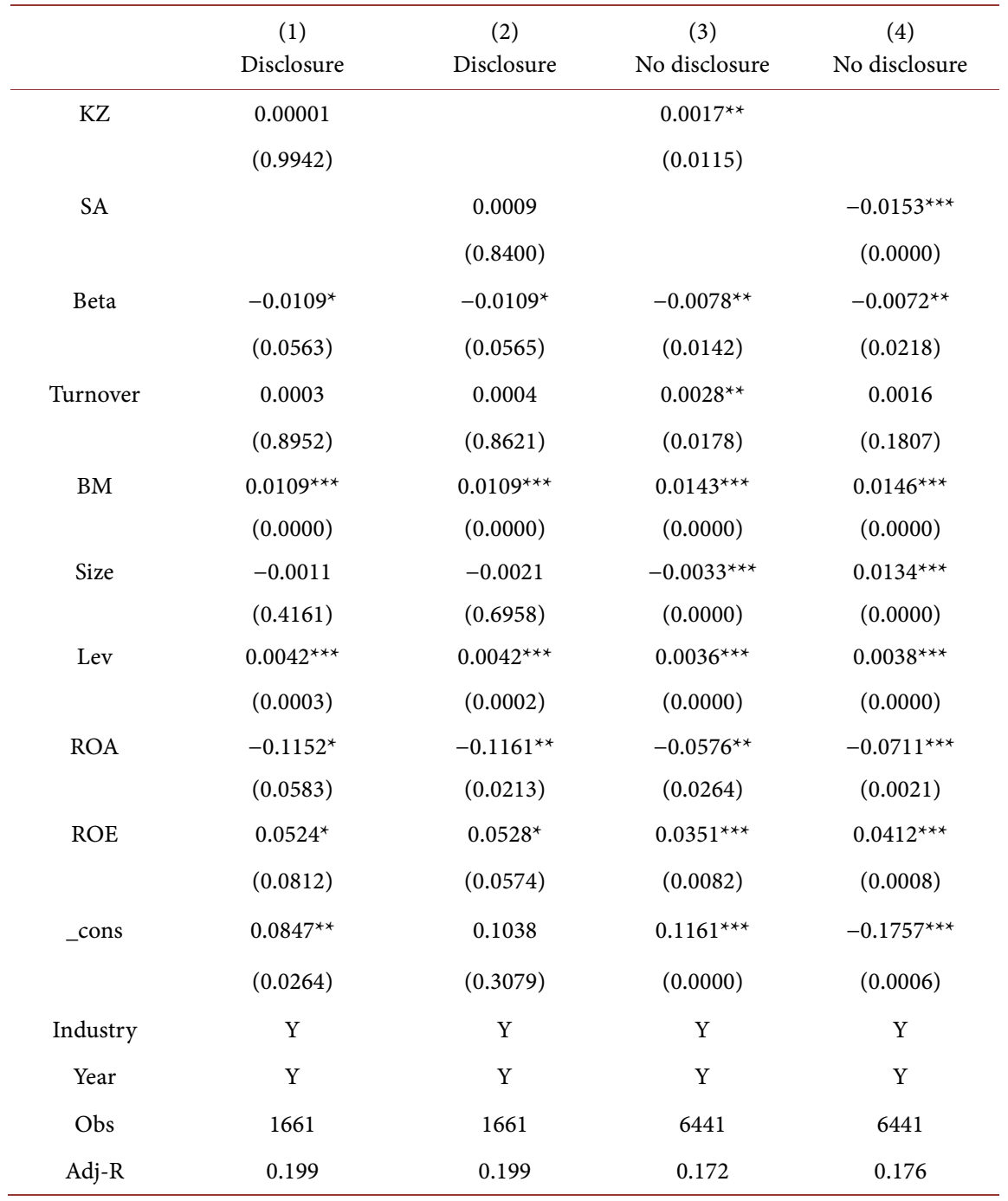


comparison of the non-disclosure in the third and fourth columns, it can be seen that the impact of the financing constraints in the first and second columns on the cost of the equity capital is not significant, while the impact of the financing constraints in the third and fourth columns is significant, which shows that the impact of the disclosure on the cost of the equity capital is not obvious in the enterprises that have disclosed the protection of the rights and interests of the shareholders.

\section{Conclusion}

In this paper, A-share listed companies in China from 2007 to 2016 are taken as the research sample, and the impact of financing constraint risk on the cost of equity capital is investigated in combination with the institutional environment of China. The regulatory effect of information disclosure on the relationship between the two is studied based on the nature of property rights and whether the protection of shareholders' rights and interests is disclosed in the financial report. The results show that: there is a significant positive correlation between the risk of financing constraint and the cost of equity capital. The greater the risk of financing constraint, the greater the cost of equity capital; the state-owned enterprises can alleviate the impact of financing constraint on the cost of equity capital; for companies that do not disclose the protection of shareholders' rights and interests in the annual report, the impact of their financing constraint risk on the cost of equity capital is more significant; state-owned enterprises have more financing channels. To some extent, it can give full play to the advantages of state-owned capital, transmit safe signals to the market and reduce the information asymmetry inside and outside the company. As an effective alternative mechanism to the quality of information disclosure, its characteristics significantly reduce the role of financing constraint risk on the cost of equity capital. The above empirical evidence shows that one of the economic consequences of financing constraint risk is that it will increase the cost of equity capital when the company refinances, and the improvement of information disclosure will help to reduce this negative effect. In order to improve the financing efficiency of Listed Companies in China, we should strengthen the protection of shareholders and creditors, gradually establish a relatively stable capital market, and strengthen the supervision of relevant departments to create a superior disclosure environment.

There are some limitations in this study. This paper mainly uses PEG model to measure the cost of equity capital, which is easy to calculate and can properly consider the risk factors, but the time series error variance is large (Easton, Ratios, \& Ratios, 2004; Botosan, 1997). Finally, in addition to these variables considered in this model, there are many factors that affect the cost of equity capital, such as media reports, which are not controlled in this paper, and may have a certain impact on the research conclusions.

However, this paper does not consider the influence of corporate governance 
factors and external environmental factors on the result, which will be explored in the follow-up study.

\section{Conflicts of Interest}

The author declares no conflicts of interest regarding the publication of this paper.

\section{References}

Almeida, H., Campello, M., \& Weisbach, M. S. (2010). The Cash Flow Sensitivity of Cash. Journal of Finance, 59, 1777-1804. https://doi.org/10.1111/j.1540-6261.2004.00679.x

Botosan, C. A. (1997). Disclosure Level and the Cost of Equity Capital. Accounting Review, 72, 323-349.

Easton, P. D., \& Ratios, P. E. (2004). PEG Ratios, and Estimating the Implied Expected Rate of Return on Equity Capital. Accounting Review, 79, 73-95. https://doi.org/10.2308/accr.2004.79.1.73

Fazzari, S. M., \& Athey, M. J. (1987). Asymmetric Information, Financing Constraints, and Investment. Review of Economics \& Statistics, 69, 481-487. https://doi.org/10.2307/1925536

Gebhardt, W. R., Lee, C. M. C., \& Swaminathan, B. (2001). Toward an Implied Cost of Capital. Journal of Accounting Research, 39, 35-176. https://doi.org/10.1111/1475-679X.00007

Hadlock, C. J., \& Pierce, J. R. (2010). New Evidence on Measuring Financial Constraints: Moving beyond the KZ Index. Review of Financial Studies, 23, 1909-1940. https://doi.org/10.1093/rfs/hhq009

Hou, K., Dijk, M. A. V., \& Zhang, Y. (2012). The Implied Cost of Capital: A New Approach. Working Paper, 53, 504-526. https://doi.org/10.1016/j.jacceco.2011.12.001

Kaplan, S. N., \& Zingales, L. (1997). Do Investment-Cash Flow Sensitivities Provide Useful Measures of Financing Constraints? The Quarterly Journal of Economics, 112, 169-215. https://doi.org/10.1162/003355397555163

White, T. M., \& Wu, G. (2006). Financial Constraints Risk. Social Science Electronic Publishing, 19, 531-559. https://doi.org/10.1093/rfs/hhj012 